\title{
Effect Characteristics of Farmers on the Level of Technology Adoption Side-Grafting in Cocoa Farming at Sigi Regency-Indonesia
}

\author{
Effendy $^{1,2}$, Nuhfil Hanani ${ }^{3}$, Budi Setiawan ${ }^{3} \&$ A. Wahib Muhaimin ${ }^{3}$ \\ ${ }^{1}$ Agricultural Economics Faculty of Agriculture, University of Brawijaya, Indonesia \\ ${ }^{2}$ Department of Agriculture Economic, University of Tadulako, Indonesia \\ ${ }^{3}$ Department of Agriculture Economic, University of Brawijaya, Indonesia \\ Correspondence: Effendy, Agricultural Economics Faculty of Agriculture, University of Brawijaya, Indonesia. \\ E-mail: effendy_surentu@yahoo.com
}

Received: August 19, 2013

Accepted: September 18, 2013 Online Published: November 15, 2013

doi:10.5539/jas.v5n12p72

URL: http://dx.doi.org/10.5539/jas.v5n12p72

\begin{abstract}
This research aimed to determine the level of adoption and effect of characteristics of farmers on the level of adoption side-grafting technology on cocoa farming. The research was conducted at Palolo District, Sigi Regency-Indonesia. Sample size as big as 98 cocoa farmers and sampling was done by simple random. The results showed the level of technology adoption side-grafting on cocoa farming was still low. Characteristics of farmers such as ethnic, age, cocoa farming experience, and frequency followed agricultural extension of significant effect on the level of technology adoption side-grafting on cocoa farming at Sigi regency-Indonesia.
\end{abstract}

Keywords: characteristics, adoption, side-grafting, cocoa

\section{Introduction}

Cocoa grew rapidly in the 1990s and making Indonesia the world's third largest exporter, after Ivory Coast and Ghana (Neilson, 2008). Cocoa farmers at Indonesia are now estimated to be 1,400,000 households, mostly small, about 2 hectares (ha) or less, even outside of Java. Cocoa prices increased very high during the economic crisis in the late 1990s actually have been brought blessing for cocoa farmers, especially at Eastern Indonesia. No exaggeration to say that the cocoa at Indonesia has contributed significant to poverty alleviation, especially in rural areas (Neilson, 2008).

Cocoa is one of Indonesia commodity and plays an important role for the economy, particularly in the supply of employment and source of income. Indonesian cocoa market opportunities open enough, both domestic and export needs. Indonesian Cocoa Association (Askindo) estimated that in 2012 the domestic needs of cocoa beans increased by about 16.7 percent from last year (240,000 tons) to 280,000 tons. Cause of increase in the needs of cocoa beans, among others: corporate plan of Guan Chong Bhd increase the production capacity of its plant in Batam by 60,000 tons per year to 120,000 tons. In addition, it was estimated, cocoa processing plant owned by PT Barry Callebaut Comextra Indonesia with of milling capacity 28,000 tons of cocoa beans per year in Makassar also has started operations in 2012 (Anonimous, 2012).

Cocoa is one of the plantation commodities which have an important role in supporting economic development at Central Sulawesi-Indonesia, that is as an export commodity. Cocoa production at Central Sulawesi in 2011 ranged from 95,589 tons (13.42\% of Indonesian production) ranks third after South Sulawesi-Indonesia (20.07\%) and Southeast Sulawesi-Indonesia (16.82\%) (Direktorat Jenderal Perkebunan, 2012).

Sigi Regency is one of cocoa producing areas at Central Sulawesi-Indonesia. But lately cocoa development is facing various problems such aslevel of crop productivity cocoa are still low. Causes of low productivity which is achieved cocoa of farmers is the presence of pests and diseases, the application of cultivation technology which is not optimal, and used plants type that have low production potential or conditions most plants have reached the age of 20 years (Basri, 2009). To overcome these problems, the government through the Movement of Improvement Production and Quality National Cocoa (Gernas), has been implemented clonal propagation technology (type) superior cocoa, such as by side-grafting. Side-grafting in addition contribute to the multiplication of superior cocoa clones, also were effective in rehabilitating unproductive cocoa trees (old/broken) (Departemen Pertanian Direktorat Jenderal Perkebunan, 2009). 
Side-grafting is a technique of propagation vegetative in which new plants that grow to be the same as the original plant. Stalk shoots/entres is taken from the most good tree of its growth and from selected clones, giving yields much, resistant to certain pests and diseases, as well as fit with the local environmental conditions, and has been applied by the Head of the Provincial Office in charge of plantations (Departemen Pertanian Direktorat Jenderal Perkebunan, 2009). When this has been known to some cocoa clones excels at Central Sulawesi-Indonesia, such as Sulawesi 1 (S1) and Sulawesi 2 (S2). Clones of cocoa S1 and S2 can be a source of budwood selection in order to increase the productivity of cocoa in Sigi regency-Indonesia through side grafting.

Technology of side-grafting besides increase production also can stimulate fruitful cocoa. Normally cocoa produce fruit on 2-3 years, but for cocoa by technology of side-grafting has been able to bear fruit at the age of 1 year and production ranges from 1.8 to 2.75 tons $\cdot \mathrm{ha}^{-1}$ (Departemen Pertanian Direktorat Jenderal Perkebunan, 2009). Side-grafting one of technology which is developed by farmers at Sigi Regency-Indonesia. Until the Year 2011 cocoa crop productivity was still around 0.67 tons ha $^{-1}$ with a total area of $27,555.10$ ha and production of 18,386.50 tons (Badan Pusat Statistik, 2012). This is because not all farmers adopt the technology of side-grafting.

The emergence technology of side-grafting as part of a sustainable farming system which is one of the answers to the reduction in productivity of cocoa in Sigi regency-Indonesia is very important to get serious attention. Technology of side-grafting in Sigi regency-Indonesia has not received full support from the government, researchers and farmers, so that is needed of steps strategic to communicate the technology to the farmers. The role of method approach in conveying an innovative so that farmers are willing to adopt the technology becomes very important to socialize side-grafting technology. Based on this context, the adoption of technology becomes very important to get in-depth attention.

In relation with this thing, then it becomes interesting to do research on the effect of the characteristics of farmers to technology adoption level side-grafting on cocoa farming at Sigi regency-Indonesia. The purpose of the research is (1) determine the level of technology adoption side-grafting on cocoa farming and (2) analyze the effect of the characteristics of farmers to technology adoption side-grafting on cocoa farming.

\section{Method}

\subsection{Place and Time of Research}

The research was conducted at the Sejahtera Village and Bulili Village at Palolo Subdistrict-Indonesia. Both of village is the center of the largest cocoa production at Palolo Subdistrict and have been using side-grafting technology in plants of cocoa and has been produce. The study was conducted from January to March 2013.

\subsection{Population and Sample}

The population in this research numbered 218 cocoa farmers. Population at Sejahtera Village 106 of cocoa farmers and at Bulili Village 112 of cocoa farmers. Samples was determined by probability sampling. Sampling was done by simple random. The number of samples was calculated by using the formula Parel et al. (1973), as follows:

$$
n=\frac{N \sum N_{h} s_{h}^{2}}{N^{2} \frac{d^{2}}{z^{2}}+\sum N_{h} s_{h}^{2}}
$$

where:

$$
\begin{array}{ll}
\mathrm{n}=\text { number of Sample } & \mathrm{N}=\text { number of population } \\
\mathrm{N}_{\mathrm{h}}=\text { number of population per village } & \mathrm{d}=\text { precision is set at } 10 \% \\
\mathrm{z}=1.645(90 \%) & \mathrm{S}_{\mathrm{h}}=\text { variance of each village }
\end{array}
$$

Number of samples from each village was determined proportionally by the formula:

$$
n_{h}=\frac{N_{h}}{N} n
$$

where:

$\mathrm{n}_{\mathrm{h}}=$ number of sample from each village

Based on the formula (2) the number of samples at Sejahtera Village totaled 48 cocoa farmers and Bulili Village totaled 50 cocoa farmers.

\subsection{Data Analysis Techniques}

Data analysis techniques which were used in this research as follows: 
1) to answer the first objective was used of descriptive statistics and

2) to answer the second objective was used multiple regression analysis with the model:

$$
Y=\beta_{0}+\beta_{1} X_{1}+\beta_{2} X_{2}+\beta_{3} X_{3}+\beta_{4} X_{4}+\beta_{5} X_{5}+\beta_{6} X_{6}+\mu
$$

where:

$\mathrm{Y}=$ level of technology adoption side-grafting (\%)

$\beta 1-\beta 6=$ regression coefficients

$\mathrm{D}=0$ for ethnic of Kaili (indigenous people)

$\mathrm{X} 2=$ age (year)

$\mathrm{X} 4=$ cocoa farming experience (year)

$\mathrm{X} 6$ = frequency follow agricultural extension (frequency)

$$
\begin{aligned}
& \beta 0=\text { intercept } \\
& \mathrm{X} 1=\text { dummy ethnic } \\
& \mathrm{D}=1 \text { for non-ethnic Kaili (immigrants) } \\
& \mathrm{X} 3=\text { education (year) } \\
& \mathrm{X} 5=\text { number of household members (people) } \\
& \mu=\text { error term }
\end{aligned}
$$

\section{Results and Discussion}

\subsection{Level of Technology Adoption Side-Grafting}

Level of technology adoption side-grafting was the ratio of the cocoa farming area were side-grafting with of the cocoa farming area which was owned by farmers. Level of technology adoption side-grafting at Sigi regency-Indonesia were shown in Table 1.

Table 1. Level of Technology Adoption Side-Grafting on Cocoa Farming at Sigi Regency-Indonesia

\begin{tabular}{ccc}
\hline $\begin{array}{c}\text { Level of Technology Adoption Side-Grafting } \\
(\%)\end{array}$ & $\begin{array}{c}\text { Frequency } \\
\text { (people) }\end{array}$ & $\begin{array}{c}\text { Percentage } \\
(\%)\end{array}$ \\
\hline 0 & 55 & 56,12 \\
50 & 3 & 3,06 \\
60 & 1 & 1,02 \\
70 & 3 & 3,06 \\
75 & 1 & 1,02 \\
80 & 5 & 5,10 \\
100 & 30 & 30,61 \\
\hline Total & 98 & 100,00 \\
\hline
\end{tabular}

Table 1 showed there were $56.12 \%$ of the farmers did not perform side-grafting on cocoa farming and $30.61 \%$ of farmers who have done side-grafting to all the cocoa which was owned. This means that the level of technology adoption side-grafting on Cocoa Farming was still low at Sigi regency-Indonesia.

Side-grafting on cocoa farming was to paste entris (branch plagiotrop) derived from types (clones) of superior cacao on rootstock cacao plants that old or have low productivity. Shoots that grew from the scion then developed into trunks and branches, which in turn produced fruit with higher productivity level according to the potential of genetic material cropping (Basri, 2009). Some researchers showed that side-grafting could increase the production and productivity of cocoa trees (Limbongan dan Langsa, 2006; Muis dan Basri, 2008).

\subsection{Factors Affecting Level of Technology Adoption Side-Grafting}

Multiple regression analysis was used to analyze the factors that affected the level of technology adoption side-grafting on cocoa farming. Level of technology adoption side-grafting on cocoa farming could be affected by the characteristics of farmers, such as of ethnic, age of farmers, farmer education, experience of cocoa farming, number of household members, and frequency of follow agricultural extension. Results of multiple regression analysis were shown in Table 2.

Table 2 showed Fstatistic $=43.119$ with probability $0.000<0.010(\alpha=1 \%)$ proved reject the null hypothesis, meant that the independent variable ethnic, age of farmers, farmer education, experience of cocoa farming, number of household members, and frequency of follow agricultural extension of affect simultaneous on the level of technology adoption side-grafting on cocoa farming.

Determinant coefficient of adjusted $\mathrm{R}$ square $=0.7226$ showed that variation the level of technology adoption side-grafting on cocoa farming could be explained by the independent variables ethnic, age of farmers, farmer education, experience of cocoa farming, number of household members, and frequency followed agricultural extension as big as $72.26 \%$, while $27.74 \%$ was explained by other factors not included in the model. Effect of each factor to the technology adoption side-grafting on cocoa farms were as follows: 
Table 2. Results of Parameter Estimation Equation Level of Technology Adoption Side-Grafting on Cocoa Farming

\begin{tabular}{lllll}
\hline Variable & Coefficients & Standard Error & probability & VIF \\
\hline Intercept & -0.381 & 15.173 & & \\
Ethnic & 20.679 & 6.041 & $0.001^{* *}$ & 1.468 \\
Age & -0.918 & 0.273 & $0.001^{* *}$ & 1.249 \\
Education & 1.738 & 4.010 & 0.666 & 2.994 \\
Experience of cocoa farming & 3.217 & 0.642 & $0.000^{* *}$ & 2.761 \\
Number of household members & 1.752 & 1.701 & 0.305 & 1.114 \\
Frequency following the & 2.865 & 1.124 & $0.013^{*}$ & 2.815 \\
agricultural extension & & & & \\
\hline Adjusted R Square 0.7226 & & & & \\
F statistic 43.119** & & & & \\
\hline
\end{tabular}

$* *=$ Significant at $\alpha=1 \%, *=$ significant at $\alpha=5 \%$.

\subsubsection{Ethnic}

Ethnic of significant effect on the level of technology adoption side-grafting on cocoa farming at Sigi regency-Indonesia at $\alpha=1 \%$. Coefficient of 20.679 meant that, immigrant farmers (non-ethnic kaili) had a level of technology adoption side-grafting on the cocoa farming as big as $20.679 \%$ higher than indigenous farmers (ethnic Kaili). This was due to immigrant farmers (Bugis, Toraja, Java, Masamba, Batak, Seko, Sanger, and Palopo) more enthusiastic to live more advanced because it was in the overseas region. They more readily accepted innovations to increase welfare.

This research relefan with of research Jasmine, Norhamidah, Suwaiba, and Nordin (2012) on the factors associated with continuance adoption of agricultural innovations among rural people at Sabah, Malaysia. This qualitative research conducted in rural areas at the City of Marudu, Sabah, Malaysia. The findings of the research showed that five major factors associated with continuance adoption of agricultural innovations were the demographic and socio-economic, psychological and cognitive attributes of leadership, communication, provision of inputs and technical assistance.

\subsubsection{Age}

Age of farmers significant effected on the level of technology adoption side-grafting on the cocoa farming $\alpha=$ $1 \%$. Coefficient of -0.918 meant that every increase in age farmers as big as 1 year could reduce the level of technology adoption side-grafting on cocoa farming as big as $0.918 \%$, with assume other factors held constant. This was due to the older increasingly farmers increasingly retain their mores. Farmers of age young more eager found new things, so they were more quickly its adopt.

This research was supported by research Paxton et al. (2011), through a 2005 survey of cotton producers in the southeastern United States. Results of this research showed that age was negatively correlated with the adoption of agricultural technologies. These results showed that young age producers were higher adopt of agricultural technology. The same thing was stated by Moga, Constantin, and Antohi (2012) elderly could lead to a negative attitude towards the use of Information and Communication Technology in Romania. However, contrary to research Xu and Wang (2012), Lestrelin et al. (2011) and Singha, Baruah, Bordoloi, Dutta, and Saikia (2012) showed the adoption did not depend on the variable age of farmers.

\subsubsection{Farmer Education}

Farmer education did not significant effect on the level of technology adoption side-grafting on cocoa farming. This was due largely less educated respondents, so it did not significant affect of the technology adoption side-grafting.

This research was supported by research Lestrelin et al. (2011) that an evaluation study in 21 villages in Laos, the technology adoption of conservation agricultural (CA) had become an important constituent of the agricultural landscape. Statistical and qualitative evidence showed that experimentation and adoption did not depend on education. The same was stated by Raut, Sitaula, Vatn, and Paudel (2011) that education did not affect the farmer's decision about the application of intensive agriculture at Nepal.

This research contrary with research of Xu and Wang (2012), that education effected technology adoption decisions by fruit growers in China. Research Singha et al. (2012) at Sonitpur Assam District, India, showed that 
the education variables had a significant positive correlation with the adoption of technology. The same thing was said by Abdullah and Samah (2013) that the level of education affected of technology adoption among farmers in Malaysia.

\subsubsection{Experience of Cocoa Farming}

Experience of cocoa farming significant effected on the level of technology adoption side-grafting on the cocoa farming $\alpha=1 \%$. Coefficient of 3.217 meant that every increase in experience of cocoa farming as big as 1 year could increase the level of technology adoption side-grafting on cocoa farming as big as $3.217 \%$, with assumed other factors held constant. This was due to the increasingly higher of experience a farmer, the more extensive their knowledge on innovation and technology, so they were more open to new technologies.

This research was supported by research Ayoola (2012) who studied the effect of socio-economic factors to the yams technology at Nigerian. Probit analysis showed that experience farming significant effected on technology adoption. The same was stated by Nyanga (2012) that the adoption of conservation agriculture technologies (CA) was quite low in most of Africa. However, Zambia had been quite successful in increasing the adoption of CA by smallholder farmers. This research had shown that previous experiences significantly increase adoption of CA.

\subsubsection{Number of Household Members}

Number of household members did not significant effect on the level of technology adoption side-grafting on cocoa farming. This was due to the number of household members mostly had not been productive, so the number of household members did not affect the level of technology adoption side-grafting.

Research Bello, Salau, and Ezra (2012) that identified the factors that affected of rice technology discontinuation at Nasarawa, central Nigeria. Household size accounted for $67.0 \%$ of the variation in the termination of rice technology adoption by farmers.

\subsubsection{Frequency Followed the Agricultural Extension}

Frequency followed the agricultural extension of significant effected on the level of technology adoption side-grafting on the cocoa farming $\alpha=5 \%$. Coefficient of 2.865 meant that any increase in the frequency followed the agricultural extension as big as 1 time could increase the level of technology adoption side-grafting on cocoa farming as big as $2.865 \%$, with assume other factors held constant. This was due to the increasingly higher of frequency followed the agricultural extension increasingly the more their knowledge of innovation and technology, so they were more open to new technologies.

This research was supported by research Ayoola (2012) who studied the effect of socio-economic factors to the yams technology at the Nigerian. Probit analysis showed that extension frequency significant effected to the technology adoption. Further Bello et al. (2012) identified the factors that affected of rice technology discontinuation at Nasarawa, central Nigeria. Characteristics of farmers such as extension contact accounted for $67.0 \%$ of the variation in the termination of rice technology adoption by farmers.

\section{Conclusion and Recommendations}

The results showed the level of technology adoption side-grafting on cocoa farming was still low at Sigi regency-Indonesia. Characteristics of farmers such as ethnicity, age, cocoa farming experience, and frequency following agricultural extension of significant effect on the level of technology adoption side-grafting on cocoa farming at Sigi regency-Indonesia. Therefore improving human resources in rural areas would increase of the technology adoption side-grafting on cocoa farming in the Sidi Regency-Indonesia.

\section{References}

Abdullah, F. A., \& Samah, B. A. (2013). Factors Impinging Farmers' Use of Agriculture Technology. Asian Social Science, 9(3), 120-124. http://dx.doi.org/10.5539/ass.v9n3p120

Anonimous. (2012). Kebutuhan Kakao Dalam Negeri 280.000 Ton. Retrieved 11 Nopember, 2012, from http://id.berita.yahoo.com/kebutuhan-kakao-dalam-negeri-280-000-ton-154412488.html

Ayoola, J. B. (2012). Socio-economic Determinants of the Adoption of Yam Minisett Technology in the Middle Belt Region of Nigeria. Journal of Agricultural Science, 4(6), 215-222. http://dx.doi.org/10.5539/jas.v4n6p215

Badan Pusat Statistik. (2012). Kabupaten Sigi Dalam Angka. Kantor Pusat Statistik Kabupaten Sigi, Sulawesi Tengah. 
Basri, Z. (2009). Kajian Metode Perbanyakan Klonal pada Tanaman Kakao. Media Litbang Sulawesi Tengah, 2(1), 7-14.

Bello, M., Salau, E. S., \& Ezra, L. (2012). Analysis of Factors Influencing iscontinuance of Technology Adoption: The Situation with Some Nigerian Farmers. Sustainable Agriculture Research, 1(2), 292-300. http://dx.doi.org/10.5539/sar.v1n2p292

Departemen Pertanian Direktorat Jenderal Perkebunan. (2009). Buku Panduan Teknis Budidaya Tanaman Kakao (Theobroma cacao L.). Gerakan Peningkatan Produksi dan Mutu Kakao Nasional.

Direktorat Jenderal Perkebunan. (2012). Buku Statistik Perkebunan Tahun 2009-2011. Retrieved from http://www.google.co.id/\#bav=on.2,or.r_qf.\&fp=e0d9043041582470\&q=Buku\%20Statistik\%20Perkebunan \%20kakao\%20Tahun\%202009\%20\%E2\%80\%93\%202011\%20pdf, diakses 11 Nopember 2012

Jasmine, J. H., Norhamidah, A. M., Suwaiba, J. Z., \& Nordin, M. (2012). Factors Associated with the Continuality of Agricultural Innovation Adoption in Sabah, Malaysia. Journal of Sustainable Development, 5(1), 47-54. http://dx.doi.org/10.5539/jsd.v5n1p47

Lestrelin, G., Hoa, T. Q., Jullien, F., Rattanatray, B., Khamxaykhay, C., \& Tivet, F. (2011). Conservation agriculture in Laos: Diffusion and determinants for adoption of direct seeding mulch-based cropping systems in smallholder agriculture. Renewable Agriculture and Food Systems, 27(1), 81-92. http://dx.doi.org/10.1017/S174217051100055X

Limbongan, J., \& dan Langsa, Y. (2006). Peremajaan pertanaman kakao dengan klon unggul melalui teknik sambung samping (side-cleft grafting) di Sulawesi Tengah. Prosiding Seminar Nasional Pengembangan Usaha Agribisnis Industri Pedesaan, Palu.

Moga, L. M., Constantin, D. L., \& Antohi, V. M. (2012). A Regional Approach of the Information Technology Adoption in the Romanian Agricultural Farms. Informatica Economică, 16(4), 29-36.

Muis, A., \& dan Basri, Z. (2008). Kajian Peningkatan Produksi dan Pendapatan Usahatani Kakao Melalui Teknik Sambung Samping. Media Litbang Sulawesi Tengah, 1(2), 78-87.

Neilson, J. (2008). Program Gerakan Nasional Percepatan Revitalisasi Kakao Nasional (GERNAS). Masukan strategis dari Forum Kemitraan Kakao Berkelanjutan (Cocoa Sustainability Partnership), ACIAR. $\begin{array}{llll}\text { Retrieved } & 11 & \text { Nopember, } & \text { 2012, from }\end{array}$ http://www.google.co.id/\#bav=on.2,or.r_qf.\&fp=442bdad5c6096e1d\&q=Program + Gerakan + Nasional + Perc epatan+Revitalisasi+Kakao+Nasional+\%28GERNAS\%29

Nyanga, P. H. (2012). Factors Influencing Adoption and Area under Conservation Agriculture: A Mixed Methods Approach. Sustainable Agriculture Research, 1(2), 27-40. http://dx.doi.org/10.5539/sar.v1n2p27

Parel, C. P., Caldito, G. C., Ferrer, P. L., De Guzman, G. G., Sinsioco, C. S., \& Tan, R. H. (1973). Sampling Design and Procedures. The Agricultural Development Council. Quezon City.

Paxton, K. W., Mishra, A. K., Chintawar, S., Roberts, R. K., Larson, J. A., English, B. C., ... Martin, S. W. (2011). Intensity of Precision Agriculture Technology Adoption by Cotton Producers. Agricultural and Resource Economics Review, 40(1), 133-144.

Raut, N., Sitaula, B. K., Vatn, A., \& Paudel, G. S. (2011). Determinants of Adoption and Extent of Agricultural Intensification in the Central Mid-hills of Nepal. Journal of Sustainable Development, 4(4), 47-60. doi: $10.5539 /$ jsd.v4n4p47

Singha, A. K., Baruah, M. J., Bordoloi, R., Dutta, P., \& Saikia, U. S. (2012). Analysis on Influencing Factors of Technology Adoption of Different Land Based Enterprises of Farmers under Diversified Farming System. Journal of Agricultural Science, 4(2), 139-146. http://dx.doi.org/10.5539/jas.v4n2p139

\section{Copyrights}

Copyright for this article is retained by the author(s), with first publication rights granted to the journal.

This is an open-access article distributed under the terms and conditions of the Creative Commons Attribution license (http://creativecommons.org/licenses/by/3.0/). 